\title{
Had Kifayah Zakah and Adequacy of Income Redistribution: A Proposal Framework
}

\author{
Bayu Taufiq Possumah
}

STEI Tazkia Bogor, Indonesia

\begin{abstract}
Social security systems traditionally serve a dual purpose: they maintain acquired living standards in the event of the materialization of social risks and combat poverty by guaranteeing adequate minimum income. In this paper we consider Zakat as an important mechanism that strengthens the economy of the entire society by providing Had kifayah as a way to redistribute income. Zakat is also a source of social security to the community, especially to those under inadequate living standards. Had Kifayah Zakat can work as a minimum standard to manage redistribution of income, thereby reducing poverty and balancing economic growth in our society.
\end{abstract}

Keywords: Had Kifayah; Zakat; Social Security; Income redistribution; adequacy

\section{INTRODUCTION}

Poverty is a classic and complex socio economic problem that has plagued human life through centuries; it has always existed and will remain for decades to come (Food and Agriculture Organization of the United Nations, 2012). Poverty persists in both rural and urban areas, in developed and developing economies, but its nature may vary from community to community, culture to culture and time to time (Hassan, 2010). Poverty has a direct effect on material progress and civil development at individual and social levels (Usmani, 2000). In many countries, international organizations and non-government organizations have introduced several programs to reduce poverty. These programs such as initiatives to create employment and market opportunities by constructing small scale industries, enable people get access to jobs and sell their goods at favourable prices. There are also programs for promoting infrastructural development by good governance and effective administration, constructing good roads to make transport and communication easy for the rural population, and promoting agriculture and farming which are the main sources of income in rural areas. All of these programs create opportunities that empower the needy (Singh, 1999).

The World Development Report (World Bank, 1990) also recommended a dual approach to reducing poverty: (i) efficient labor-intensive growth based on appropriate market incentives, physical infrastructure, institutions and technological innovations; and (ii) adequate provision of social services, including primary education, basic health care and family planning services. Generally, in monetary terms, poverty is measured based on the income levels or consumption per capita or per household. Bretton Woods Project (2016) informed that in October 2015, as differences in the cost of living across the world continue to evolve, the World Bank published its updated international poverty line (IPL) and announced its estimate of the number 
of people living in extreme poverty globally. The IPL, which came to prominence with the dollar-a-day figure devised by the Bank in 1990, is revised periodically in line with new data from the independent International Comparison Program (ICP) hosted by the World Bank. The new figure of $\$ 1.90$ is based on ICP's purchasing power parity (PPP) calculations and represents the international equivalent of what $\$ 1.90$ could buy in the US in 2011. The new IPL replaces the $\$ 1.25$ per day figure, which used data from 2005.

According to the World Bank, "global poverty rates will have fallen from 902 million people or 12.8 per cent of the global population in 2012 to 702 million people, or 9.6 per cent of the global population [in 2015]". The Bank's announcement highlighted a change in the composition of poverty, noting that "in 1990, East Asia accounted for half of the global poor, whereas some 15 per cent lived in Sub-Saharan Africa; by 2015 forecasts, this is almost exactly reversed: SubSaharan Africa accounts for half of the global poor, with some 12 per cent living in East Asia.” (Bretton Woods Project, 2016). World Bank reported that for the current 2016 fiscal year, low-income economies are defined as those with a GNI per capita, calculated using the World Bank Atlas method, of $\$ 1,045$ or less in 2014; lower-middle-income economies are those with a GNI per capita between $\$ 1,046$ and $\$ 4,125$; upper-middle-income economies are those with a GNI per capita between $\$ 4,126$ and $\$ 12,735$; and high-income economies are those with a GNI per capita of $\$ 12,736$ or more (The World Bank, n.d.).

The main objective of the present paper, however, is to explore the relationships between poverty and inequality in income distribution, social security and poverty, and last but not least how the Kifayah zakah mechanism may be used as an instrument of redistribution of income and social security to reduce poverty levels and deliver the minimum standard of living.

\section{POVERTY AND INCOME \\ INEQUALITY DISTRIBUTION: REVIEW OF ISSUES}

Many researches show that, sometimes, even poverty and inequality are studied separately, whereas in reality there are significant trade-offs between both issues. Cornia and Court (2001) highlighted the five main issues related to the second wave of globalisation. First, inequality has risen since the early-mid 1980s. Second, the traditional common factors causing inequality, such as land concentration, urban bias and inequality in education are not for the agents of worsening the situation. Third, the high level persistence of inequality makes poverty reduction difficult. Fourth, a high level of inequality can curtail the rate of growth and lead to undesirable political and social outcomes. Some scholars such as Kanbur (2010) and Basu (2006), in trying to explain the relationship between globalization, inequality and marginalization that are theoretically and empirically interconnected, had formalized the concept of "poverty minimizing level of inequality", arguing that they are in reality interconnectedas well .

Changes in per capita income are the main determinants of changes in poverty. Even though the debate on whether the degree of inequality has increased or decreased over time remains unsolved, inequality still remains high. However, efforts towards maximizing per capita income might not place sufficient weight on poverty and inequality reduction as well in this era of fast global integration (Basu, 2006).

Small changes in income distribution can have a large effect on poverty alleviation as visualised by a simple arithmetical example. We imagine a country where the share of national income that goes to the poorest 20 percent of the population increases from 6 percent to 6.25 percent. A change in income distribution of a quarter of one percent would barely affect 
the Gini coefficient, but for the poor this represents a 4 percent increase in their total income. Such a small redistribution would have the same effect on poverty alleviation as doubling the annual growth of national income from 4 percent to 8 percent, which is necessary to achieve the Millennium Development Goal (MDG) 1. This is in reality the projected growth rate recommended for many African countries as seen in examples from White and Anderson (2001). The effect is also confirmed by evidence from Cote d'Ivoire and Bangladesh (Wodon, 1999). Again, a numerical example helps to show the importance of distribution of wealth for poverty. In Table 1, distribution 1 has only half the headcount of 2, and compares favourably with 3 , but its poverty gap and gap squared are higher than those in both 2 and 3. This is only because its Gini coefficient is marginally higher. Similarly, distribution 2 has lower poverty gap and poverty gap squared measures than 3 , although its headcount is considerably higher. Again this is due to very marginal changes in the Gini coefficient.

According to Dabla-Norris, et al. (2015), there are some factors that influence income inequalities such as:

- Global economic trends where inequality has risen despite opening new markets and bringing growth opportunities in countries rich and poor alike.

- Technological change. Technological advances have contributed to rising income inequality in OECD countries, accounting for nearly a third of the widening gap between the 90th and the 10th percentile earners over the last 25 years (Organisation for Economic Cooperation and Development, 2011).

- Trade globalization. Recent studies on relation between trade globalization and inequality do not focus on poverty impacts but rather on the distributional consequences of globalization. Global trade openness potentially raises the skill premium, but could also increase real wages by lowering (import) prices (Munch \& Skaksen, 2009).

- Financial globalization. Financial globalization can facilitate efficient international allocation of capital and promote international risk sharing. At the same time, increased financial flows, particularly foreign direct investment (FDI) and portfolio flows have been shown to increase income inequality in both advanced and emerging market economies (Freeman, 2010).

- Redistributive policies. Increase in net income inequality points to gaps in existing tax-and-transfer systems to counteract rising market inequality. Redistributive impact of conditional cash transfers varies widely across countries, reflecting differences in both the size and progressivity of these transfers.

Inequality of income describes the uneven income distribution of the community in an area or region at a specific time. There are some patterns to the relationship between poverty and income inequality as follows:

- All of society has high income (no poor) but higher-income inequality.

- All of society has high income (no poor) and the inequality of incomes are low (the best pattern).

- All of society has low income (all poor) and higher-income inequality.

- All of society has a low income (all poor) but inequality of incomes is low.

- The level of public income varies (mostly poor and non-poor), and higher-income inequality is reported.

- The level of public income varies (mostly poor and non-poor) but inequality of incomes is low.

There are several methods to measure the inequality of income distribution that affect the poverty level. It is divided into two approaches: axiomatic and stochastic dominance. The first approach is often used in the literature with 
three parameters: the generalized entropy (GE), the size of Atkinson index, and Gini coefficient. The formula of GE is:

$$
\begin{gathered}
\operatorname{GE}(\alpha)=\left(1 /\left(\alpha 2-\alpha \mid(1 / \mathrm{n}) \sum\left(\mathrm{yi} / \mathrm{Y}^{\wedge}\right) \alpha\right.\right. \\
-1 \mid \\
\mathrm{i}=1
\end{gathered}
$$

$\mathrm{n}=$ the number of individuals (people) in the sample,

$\mathrm{yi}=$ the income of the individual $(\mathrm{i}=1,2 \ldots$ ..n), and

$\mathrm{Y}^{\wedge}=(1 / \mathrm{n}) \Sigma$ yi is a measure of average income of the GE's value.

A GE value of zero (0) means an equitable distribution of income (income of all individuals in the sample), and 4 means that there is a very large gap. This first parameter measures the magnitude of the differences in incomes between the different groups within the distribution, and has a real value.

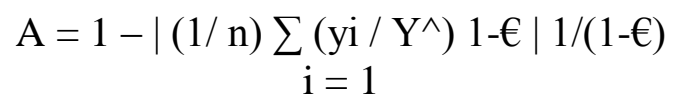

$€$ is the parameter of inequality, where $0<€<1$ is the higher value of $€$ (increasingly unequal distribution of income). Its value ranges from 0 to 1 , such that a value of 0 (zero) means no bias in the distribution of income.

For the third part of the measuring instrument by this approach, the axiom used in the empirical studies on the gap in income distribution is the Gini coefficient; the formula here is as follows:

$$
\begin{array}{r}
\text { Gini }=\left(1 / 2 n 2-Y^{\wedge}\right) \sum \sum|y i-y i| \\
i=1 j=1
\end{array}
$$

Gini coefficient values are in the interval of 0 - 1, with the caption:

- If the value is, 0 (zero), it means: perfectly equal income distribution (everyone gets the same portion of the income).

- If the value is 1 (one), it means complete inequality in the distribution of income, meaning that one person (or a group of beneficiaries) in a country enjoys all the income of the country.

The main idea for the calculation of Gini coefficient is derived from the Lorenz curve. The Gini coefficient is the ratio of: (i) the area in the graph that lies between the Lorenz curve and the line of perfect equality (which forms an angle of $45^{\circ}$ from the point 0 intersecting the $\mathrm{y}$ and $\mathrm{x}$ axis) to (ii) the triangle area between the equal lines and the $y-x$ axis, The higher the Gini ratio, or in other words the closer the value is to 1 or further away the Lorenz curve from the $45^{\circ}$ line, the greater the level of inequality in income distribution.

Another commonly used measurement approach, especially by the World Bank, is to classify a population into three groups; 40 percent of the population with low income, 40 percent of population with middle-incomes, and 20 percent of the population with high incomes. Furthermore, inequality of income is also measured in terms of the income enjoyed by 40 percent of the low income population. According to World Bank criteria, the level of inequality in income distribution is declared high if 40 percent of the lowincome population groups receive less than 12 percent of total income; the level of inequality is moderate if the group receives 12 percent to 17 percent of total income; and inequality is considered low if the group receives more than 17 percent of total income.

Foster, et al. (1984) introduced three indicators to measure the level of poverty; these indicators are used in many empirical studies as follows:

- The first indicator is the incidence of poverty, measured in terms of the percentage of the population who live in families with per capita consumption expenditure below the poverty line. The index is often known by the $\mathrm{H}$ ratio.

- The second indicator is the depth of poverty that illustrates the depth of poverty (IJK), or the so-called poverty gap index. This index 
describes the difference in the average income of the poor from the poverty line as a proportion of the line with the formula:

$\mathrm{Pa}=(1 / \mathrm{n}) \sum \mathrm{i}[(\mathrm{z}-\mathrm{yi}) / \mathrm{z}]$ a for all $\mathrm{yi}<\mathrm{z}$

$\mathrm{Pa}$ index is sensitive to the distribution if $a>1$. Section [ $(z-y i)$ $/ z]$ is the difference between the poverty line (z) and income level of the first group of poor families (yi) in the form of a percentage of the poverty line, while $[(\mathrm{z}-\mathrm{yi}) / \mathrm{z}]$ is an exponent percentage of the amount of income. When the amount of income of the poor is divided by the population (n), the $\mathrm{Pa}$ index is produced.

- The third indicator is the severity of poverty as measured by the poverty severity index (CCI). This index is equal to the IJK. However, CCI can also measure the income gap among the poor or the distribution of expenditures among the poor population. This index is also called distributionally sensitive Index and also used to determine the intensity of poverty. The existence of these two indicators (other than the $\mathrm{H}$ ratio) is useful to describe the weakness of the $\mathrm{H}$ ratio, which could not describe the severity of poverty in a country.

Poverty researchers have been long interested in the other two factors: the amount of income shortfalls of the poor and the magnitude of inequality in income distribution among the poor. With the assumption of ceteris paribus, the highest the average magnitude of the shortfall in income of the poor, the larger the gap of income among the poor is, and greater the tendency for poverty to increase. The development of the above rationale is evident in the Sen Poverty index, which incorporates these two factors, namely the Gini coefficient and the $\mathrm{H}$ ratio:

$$
\mathrm{H}: \mathrm{S}=\mathrm{H}[\mathrm{I}+(1-\mathrm{I}) \mathrm{Gini}]
$$

where (I) is the average amount of the deficit of the poor, expressed as a percentage of the poverty line and the Gini coefficient which measures inequality among the poor. Thus, when one of these factors increase, the poverty rate also increases (as measured by $\mathrm{S}$ ).

Unequal distribution of income, besides affecting poverty, also hampers the economic growth of a country. The World Development Report 2000/2001 (World Bank, 2001) concludes that better distribution is possible without a reduction in economic growth. Economic theory does not tell us why or how inequality may affect growth (Atkinson, 1997). As a result, research on this relationship tends to be ad hoc, and the evidence conjectural. The links have mainly been explained in terms of political economy, economic, or social factors. The following highlights a few explanations:

Political economy: Inequality can be thought of as the difference between the mean and the median voter. The median voter will lobby for higher taxes on the rich, leading to a disincentive to save and invest, and thus reduced economic growth. This earlier political economy line of argument, while commonly cited, is not well supported through evidence. A more recent argument suggests that inequality creates political instability that leads to lower investment (Alesina \& Perotti, 1993) and more resources being wasted bargaining over the distribution of rents (Rodrik, 1997). Instability also reduces the government's ability to react to shocks, and - in its more extreme form - leads to direct and opportunity costs due to violence (Bourguignon, 1998).

Economic factors: Economic factors of why inequality reduces growth centre on capital market imperfections and also hinge on the role of the poor, not only as beneficiaries but also as contributors to economic growth. Due to credit rationing, the poor often cannot afford the minimum 
initial investment in education or other investments, or cannot get insurance for their investments, even if they are profitable, since they lack collateral. Thus, distribution of initial asset has a negative effect on subsequent economic growth. Birdsall, et al. (1996) found that the poor's savings rate is exceptionally high when they can expect higher returns for their labour and investment. If the poor are provided with greater incentives to invest/work their income will rise, national income will increase, and inequality will fall.

Social factors: Social inequality may create self-fulfilling expectational equilibria with lower growth. If workers are paid according to social class, gender or ethnicity, rather than by what they achieve, this reduces the incentive to work/earn more (Bourguignon, 1999).

We may see how poverty, inequality and growth interact with one another through a set of two-way links in the figure below (Naschold, 2002). Some of these links (A, B and $\mathrm{C}$ in Figure 1) can be explored separately, but often one influences another causing indirect effects. For instance, inequality can indirectly influence poverty as inequality affects growth (B) and growth in turn influences poverty (C). The figure describes how inequality and poverty affect each other directly (A). Section 2.2, through its discussion of links (B) and (C), shows how they interact indirectly through growth.

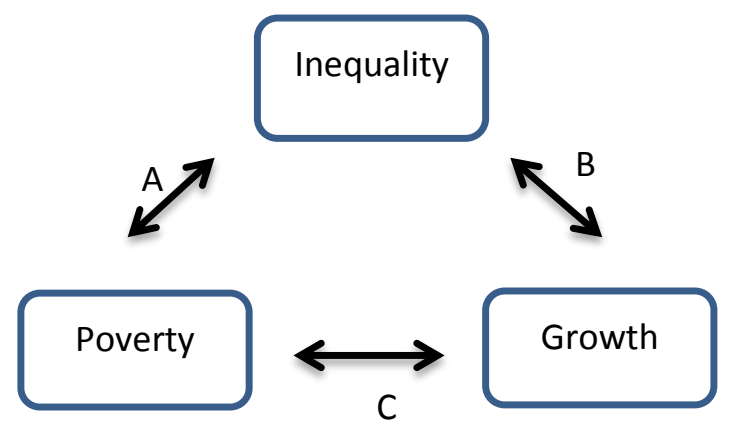

Figure 1. Interaction between Poverty, Inequality, and Growth

\section{ZAKAT BASED SOCIAL SECURITY AND INCOME REDISTRIBUTION}

Redistribution of income means distributing the income from the wealthy group to the poor communities, in the form of either taxes or other charges. Income redistribution is a form of social security provided by the state to the public. Rather than public spending, Social security is a form of social investment that, based on two main pillars (redistribution of income and social solidarity), is profitable in the long term (Spicker, 1995).

The social security system according to Reyda (1994) consists of components of active labor-power market, social insurance and social assistance as well as demogrant. The essence of social security in principle is that it covers the provision of health services to the entire population and the pensioners.

International Labor Organisation (2003) defined social security as "the protection that a society provides to individuals and households to ensure access to health care and to guarantee income security, particularly in cases of old age, unemployment, sickness, invalidity, work injury, maternity or loss of a breadwinner". The International Social Security Association (ISSA as cited in Kahf \& Al Yafai, 2015) defines social security as follows: "social security may be defined as any program of social protection established by legislation, or any other mandatory arrangement, that provides individuals with a degree of income security when faced with the contingencies of old age, survivorship, incapacity, disability, unemployment or rearing children. It may also offer access to curative or preventive medical care. In this case, social security can include social insurance programs, social assistance programs, universal programs, mutual benefit schemes, national provident funds, and other arrangements including marketoriented approaches that, in accordance 
with national law or practice, form part of a country's social security system"

Social security generally comprises of the five schemes commonly used in the UK. First, social insurance or the contributory benefits scheme is a program funded by contributions from employees, employers, and governments; the program benefits are paid to everyone who has paid their contributions. This program is intended to replace any loss or interruption of income due to reasons such as job loss, illness, retirement and death of the breadwinner. The second type, categorical or universal benefits, is a program funded from general taxes; program benefits are paid to the people who fit the program's target categories such as households with children, or people with disabilities. Third, tax-based benefits, is a program that uses the tax system to provide benefits (tax credits) to people who have income below the threshold of non-taxable income. Fourth, occupational benefits, is a program where benefits such as pensions, sickness and maternity benefits are paid by the employer. This program is regulated by the government. Fifth, social assistance or means-tested benefits, is a program funded by general tax; the program benefits are paid to low-income people according to their household situation. Examples include giving aid to the people with low income who cannot cover their basic needs.

In the United States, the term social security refers to the schemes covered under the Federal Old Age, Survivors and Disability Insurance (OASDI) program. These programs provide benefits for retirement, disability, safety and death of the breadwinner of a family. However, this program does not cover unemployed people (unemployment insurance) or social assistance that uses income as a basis for determining those worthy of assistance (mean-tested). Along with a program that provides assistance in the form of goods (means tested assistance in kind) such as food stamps, and services for the poor (means tested services for the poor) such as medical Clinique's and public housing, this social assistance program is categorized as welfare or social welfare.

\section{HAD KIFAYAH OF ZAKAT BASED ADEQUACY OF INCOME REDISTRIBUTION}

Redistribution (personal distribution) in Islam has social-economic policy implications for the government or a philanthropy initiative. It can be imperative or not in other regions. For example, Zakah, household expenditure, heritage, kafarat, and nadzar are of imperative. Sometimes, it is also obligated by the government so as to make zakat visible. Philanthropy measures such as sadaqoh, hibah and wasiah are of this nature. Redistribution, as mentioned by Zarqa and Al Jarhi (2007) should meet at least the following objectives: (i) fight against poverty, in light of the teachings to the children of Adam (this is the ultimate goal); (ii) purify the donors; and (iii) reduce inequality (the second purpose of redistribution). Islam is the only religion that systematically pursues this goal and regulates the supporting instruments through zakat or direct redistribution. Fair and equitable distribution of income and wealth is actually based on the concepts of justice or falah (wellbeing) and happiness for the whole community. In this context, it is noteworthy that the concept of redistribution does not stand alone but is closely linked to the ideology of the society charity engaging. That's why capitalism advocates unlimited freedom and private property ownership in the production areas and ends up with inequality in the distribution of wealth while, another school of thought, communism curtails individual freedom and private property ownership.

The objective of redistribution of wealth and income is to create socioeconomic justice. It is regarded as an integral part of Islam and a moral philosophy based on a definite commitment to the brotherhood of humanity (Chapra, 
2000). Justice and brotherhood are two elements that cannot be separated, and both can be realized by a system of redistribution of wealth and income. Redistribution within Islam is different from the capitalist system or socialist redistribution. Islam does not only emphasize the social community aspects but also the spiritual aspect, namely carrying out one's duties as a servant of God. According to Samuelson (1989), in the conventional economic order, the assistance to the poor is only voluntary. In this context, there is no policy of direct transfer obliging high-income groups to transfer their surplus wealth to low-income groups. The only way by conventional economics for the redistribution of income is transfer (visible transfer programs) whereby the government makes efforts to redistribute income by allocating tax advantages to the low-income groups. Justice requires us not to be selfish, and rather act equitably (Siddiqi, 2004). Redistribution system is an attempt to enforce the fair distribution of wealth and income in society. Apart from religious duty, a suggestion to convey the excess wealth to the needy can serve as the driving factor for the redistribution of wealth and income.

According to Veit-Wilson (1998), the problem with the notion of minimum incomes is that, what is being judged is the adequacy of income levels for achieving some specified minimal level of living. What that specification is, and what the context of evaluation of the minimal level of living is, have to be arguable and justified in its social context. There cannot be a free-floating and universally acceptable criterion of 'adequacy'; it can be argued only in terms of answers to real-life questions such as adequacy for what? Adequacy for how long? Adequacy for whom and who says? (Dubnoff, 1985) The last question raises the issue of the authority to determine and validate the meaning of adequacy. Based on Adam Smith's Custom of the Country, does authority in this context pertain to power holders' authority or the authority that derives from the values and experience of the population as a whole? Social research methods may be used to discover what the population as a whole regards as the answers to the first three questions, or power holders can arrogate to themselves the right to answer them, as they commonly do.

The measurement division of income in zakat mentions a concept known as had al-kifayah, which in general is a tool for measuring poverty. Quite simply, it is used to measure the adequacy of expenditure, by comparing the gross income and minimum spending of the family or the individual. Using this principle, more specific and precise decisions were obtained in determining the level of one's zakat applicant, as to whether they are rich, poor or indigent (absolutely poor).

The Management Fatwa of distribution of Zakat Selangor provides a definition of had al-Kifayah as 'the distribution of zakat to asnaf (needy) and poor who have to meet their real, basic needs. Correspondingly, the zakat institutions actually apply this method for a more accurate determination of the poor and a more focused and well-managed distribution of zakat. We should also understand that the institution of zakat takes into account the six basic needs of human life. The needs are shelter, food, clothing, education, health and transportation. These items are the basic needs for every human being. Thus, if the household income per month is not able to meet these minimum requirements, the persons belonging to that household are eligible to be considered either poor or indigent (fakir).

Most of zakat institutions use financial approach based on Had Kifaya methods (zakat average poverty line) for measuring poverty. Had Kifaya (HK) method is almost the same as the Average Poverty Line (APL) as it uses income as a variable to determine whether an individual or household is poor (JAWHAR, 2007). APL is defined as the income needed to 
meet the minimum needs including food, health, clothing, education, recreation, transportation, fuel and rent. APL was established by the Economic Planning Unit (EPU) of the Prime Minister, while the Had Kifayah is determined by the institution of zakat of each state.

Had Kifayah plays a role in determining the level of income required by households to meet their daily needs. It is calculated based on several variables such as the number of members in the household, age group, etc. Department of Awqaf, Hajj and Zakat Malaysia (JAWHAR) has outlined some of the key components in determining the needs of Had Kifaya such as shelter, food, clothing, health, education and transport based on Maqasid al Sharia (Objective of Syariah) as described by Qardhawy (2000). However, it is up to each zakat state institution to determine the need level of each these components. It is important to note that Had Kifayah varies and depends on the number of household members in the household and their ages. The using of Had Kifaya is intended to facilitate the determination of the absolute poor. Qardhawi (2000) and Ahmad (2001) recommended that the distributed amount of zakat should at least meet the minimum cost of living and the basic comforts for the recipients and their dependents. A certain amount of zakat is necessary to ensure the continuity of the quality of life. In other words, the intended effect of zakat distribution is to achieve a fair standard of living or meet the basic needs (daruriyyat) and comforts (hajiyyat).

To address the problems of poverty, we can help the poor to achieve "selfsufficiency" through zakat by six elements that can be identified and tracked as follows:

\footnotetext{
- $\quad$ Income and economic assets

- Educational skills

- Housing and environment

- Access to healthcare and other social services as needed

- Close personal ties, as well as networks with other people
}

- $\quad$ Personal resourcefulness

The World Bank also recommends a six-pronged approach o tackling inequality of income distribution that can be seen in everyday life in most of the countries:

Early childhood action focused on better nutrition

Universal health coverage

Universal access to good schools

Cash transfers to poor families

Better roads and electrification

Progressive taxation to transfer resources from the rich to the poor.

\section{MECHANISM AND MEASUREMENT}

In relation to social security, redistribution of income can be vertical and/or horizontal. Vertical redistribution refers to the transfer of money from the rich to the poor. In this context, social security is a form of support from the rich citizens to citizens who are weak economically.

Horizontal redistribution is "intergroup" money transfer, from one group to another group, for example, from men to women, from adults to children, or from teenagers to the elderly. Horizontal redistribution also can be "inter-personal", from one part of an individual's life-cycle to another. Spicker (1995) called this scheme as "income smoothing". In this context, Spicker (1995) explains that social security essentially is the financial support given to children who would pay when they are grown; given to the sick who would pay when healthy; or given to the pensioners who would have paid when they were working. In addition, there are several techniques of redistribution of income, as follows:

a. Cash transfer

Cash transfers are divided into several approaches as follows:

- Negative Income Tax or a guaranteed annual income

- Cash transfer is given to families that are entitled, with the transfer amount depending 
on the amount of income and family size. The more poor the family, the more is the financial aid received from the government.

- Demogrant is a form of cash transfer in which all demographic groups receive the same amount. The amount transfer will not decrease with increasing growth rates.

- Wage Rate Subsidies (WRS)

WRS is a government-initiated transfer that increases the level of net labor wage. The higher the market wage rate, the lower the WRS subsidy would be, but the workforces who earn high wages also continue to acquire this WRS.

b. Transfer of Money and Goods

In reality, the cash transfer can also be given partly in the form of goods. This form is intended to minimize misuse of funds. In fact, the assistance provided by the government is not usually received immediately by the public due to the inaccuracy of targeting. Therefore, the government should be more selective in distributing assistance, so that the government targets will be achieved. It can be done by:

- Direct progressive income tax, which means that the rich are required to pay taxes at a greater rate compared to the poor, so that the poor will be helped.

- Granting or direct provision of individual consumption goods and services for the needy. Examples are provision of community health centers in rural and sub-urban areas, improvement of nutritional programs, water supply, and rural electrification. This assistance is very effective and helpful. c. Public Employment Program

This comprises a government welfare program in the form of employment opportunities in the public sector combined with "cash or in-kind transfer" program.

When planning a pilot project of zakat-based adequacy scheme, the government or zakat institution should consider the following key points:

- Identify the priority social security needs of the community, based on the income level in the target areas;

- Develop a flexible programme for the poor that could allow a mix of options to accommodate individual and household needs and capacity to pay premiums;

- Develop the administrative infrastructure for establishment of the fund, collection of contributions and process of claims;

- Develop a model of linking the micro-insurance schemes with the national social security schemes

- Determine the role of the key stakeholders in national and local governments, NGOs and the service delivery agency;

- The potential for subsidies to be provided to the contributors to assist in the promotion of the schemes and to support their short-term sustainability

- Establish appropriate options for pooling of funds, reinsurance and guarantees against unanticipated situations;

- Improve knowledge and capabilities of local resources in implementing the social security system; 
- The duration of the trial run and the future of the scheme after the trial period. The pilot scheme could assess the suitability and effectiveness of the scheme

- Programmes and schemes for informal economy segments such as urban, rural and occupational groupings;

- Administrative processes and costs;

- Group dynamics such as group building, management and sustainability;

- Training of group leaders and group facilitators;

- Providers of services, local government, social security organisations, NGOs and private companies;

- Financial impact of fully selffunded and subsidised schemes; and

- Most appropriate models for extension to other areas.

To determine a fair standard of living, we can use some measurement of poverty such as the as had kifayah Zakah based approach to adequacy of income. This scheme can be a useful mechanism to provide social security to the needy.

\begin{tabular}{|c|l|}
\hline $\begin{array}{c}\text { Measurement } \\
\text { Method }\end{array}$ & \multicolumn{1}{|c|}{ Purpose of Measure } \\
\hline $\begin{array}{c}\text { Current poverty } \\
\text { thresholds }\end{array}$ & $\begin{array}{l}\text { Determine whether persons living } \\
\text { in a family are officially poor. }\end{array}$ \\
\hline $\begin{array}{c}\text { Experimental } \\
\text { poverty } \\
\text { thresholds }\end{array}$ & $\begin{array}{l}\text { Provide reasonable thresholds to } \\
\text { derive poverty statistics }\end{array}$ \\
\hline $\begin{array}{c}\text { Family budgets } \\
\text { Family } \\
\text { expenditures }\end{array}$ & $\begin{array}{l}\text { Estimate what it costs a working } \\
\text { family of four to live }\end{array}$ \\
\hline $\begin{array}{c}\text { Material hardship } \\
\text { determine const-of-living indexes. }\end{array}$ & $\begin{array}{l}\text { Identifies individuals who do not } \\
\text { consume minimal levels of goods } \\
\text { and services }\end{array}$ \\
\hline $\begin{array}{c}\text { Median family } \\
\text { income }\end{array}$ & $\begin{array}{l}\text { Estimates the income of the } \\
\text { family at the middle of the income } \\
\text { distribution. }\end{array}$ \\
\hline $\begin{array}{c}\text { Per capita } \\
\text { personal income }\end{array}$ & $\begin{array}{l}\text { Presents the nation's personal } \\
\text { income on a per person basis }\end{array}$ \\
\hline $\begin{array}{c}\text { One-half median } \\
\text { family income }\end{array}$ & $\begin{array}{l}\text { Provides a means for comparative } \\
\text { analysis of poverty status. }\end{array}$ \\
\hline \multicolumn{2}{|c|}{$\begin{array}{l}\text { Zakah based Adequacy of } \\
\text { income Redistribution }\end{array}$} \\
\hline
\end{tabular}

Source: Author (2016)

Figure 1. Summary of the Measurement

\section{CONCLUSION}

Zakat is one medium that can help individual Muslims who are facing problems in their economic life. Zakat institutions are very important in the system of zakat. It is an intermediary between the payer and the recipients (asnaf). His responsibility is very great which is to ensure the collection and the distribution of zakat to the needy with efficient and effective. If the institution is fails to function properly, then the zakat system will not be successfully implemented. Zakat institutions need to show the high values of Islam, such as trust and fairness in the management of zakat.

Nowadays, zakat management also require the managers with other sciences 
background such as management, entrepreneurship, technology and so on. This ultimately will increase the level of professionalism of the zakat management, increase zakat payer's confidence and will enhance the zakat funds in the Islamic financial system which ultimately will increase the distribution to the recipients. Thus, hopefully alleviate the poverty Islamic community and strengthen the social security in Muslim community. It is desirable to ensure that at least the quality of life of asnaf (recipents) is better than the other communities in Malaysia, even their income is below the poverty level. In managing the distribution of income more fairly, the government can do these programs such as follows:

- The government should create the programs such as granting soft community loan, running various development programs of laborintensive and business development (small-scale industries), provide the guaranteed access to the basic needs for the poor as well as cooperating with local and foreign private company to run the program of corporate social responsibility (CSR).

- The social security programs are realized through the provision of rice (Raskin), direct cash transfers (BLT), BOS, JPSBK, soft community loan (Kredit Usaha Rakyat), PNPM Mandiri program and others.

\section{REFERENCES}

Ahmad, M. P. S. (2001). Kaedah Pengagihan Dana Zakat: Satu Perspektif Islam. In N. M. N. Hassan (Ed), Kaedah Pengagihan Dana Zakat: Satu Perspektif Islam. Kuala Lumpur: IKIM

Alesina, A., \& Perotti, R. (1993). Income Distribution, Politicial Instability and Investment. NBER Working Paper No. 4486.
Atkinson, A. B. (1997). Bringing income distribution in from the cold. The Economic Journal, 107(441), 297321.

Basu, K. (2006). Globalization, poverty, and inequality: What is the relationship? What can be done?. World Development, 34(8), 1361-1373.

Birdsall, N., Pinckney, T. C., \& Sabot, R. (1996). Why low inequality spurs growth: savings and investment by the Poor. Washington DC: InterAmerican Development Bank

Bourguignon, F. (1998). Crime as a Social Cost of Poverty and Inequality: A Review focusing on Developing Countries. Paris: DELTA.

Bourguignon, F. (1999). Absolute Poverty, Relative Deprivation and Social Exclusion. Berlin: DSE.

Bretton Woods Project. (2016). The World Bank's updated international poverty line, a case of poor measurement?. Retrieved from http://brettonwoodsproject.org

Cornia, G. A., \& Court, J. (2001). Inequality, growth and poverty in the era of liberalization and globalization. Policy Brief No. 4. Helsinki, Finland: UNU World Institute for Development Economics Research.

Chapra, M. U. (2000). Islam dan Tantangan Ekonomi. Jakarta: Gema Insani Press.

Dabla-Norris, M. E., Kochhar, M. K., Suphaphiphat, M. N., Ricka, M. F., \& Tsounta, E. (2015). Causes and consequences of income inequality: a global perspective. International Monetary Fund.

Dubnoff, S. (1985). How much income is enough? Measuring public judgements. Public Opinion Quarterly, 49(3), 285-299.

Food and Agriculture Organization of the United Nations. (2012). Globally almost 870 million chronically 
undernourished - new hunger report. Retrieved from http://fao.org

Foster, J., Greer, J., \& Thorbecke, E. (1984). A class of decomposable poverty measures. Econometrica, 52 . 761-776.

Freeman, R. (2010). Does Inequality Increase Economic Output?. Controversies about Inequality. Stanford, CA: Stanford University Press.

Hassan, K. (2010). An Integrated Poverty Alleviation Model Combining Zakat, Awqaf and Micro-finance: Proceedings of the Seventh International Conference - The Tawhidi Epistemology: Zakat and Waqf Economy. Bangi Malaysia.

International Labor Organisation. (2003). Facts on social security. Retrieved from http://ilo.org

JAWHAR. (2007). Manual Pengurusan Zakat. Putrajaya: Jabatan Perdana Menteri.

Kahf, M., \& Al Yafai, S. (2015). Social security and zakah in theory and practice. International Journal of Economics, Management and Accounting, 23(2). 189-215.

Kanbur, S. R. (2010). Protecting the poor against the next crisis. Retrieved from http://kanbur.aem.cornell.edu

Munch, J. R., \& R. Skaksen. (2009). Human Capital and Wages in Exporting Firms. Working Paper 092006. Copenhagen: Copenhagen Business School.

Naschold, F. (2002). Why inequality matters for poverty. ODI Inequality Briefing Paper, 2.

Organisation for Economic Co-operation and Development. (2011). Divided we stand: Why inequality keeps rising. Paris: OECD Publishing.

Qardhawi, Y. (2000). Fiqh al-Zakah (M. Kahf, Trans.). Jeddah: Scientific Publishing Centre, King Abdulaziz University.
Reyda, G. (1994). Social insurance and economic security. Englewood Cliffs, NJ: Prentice Hall.

Rodrik, D. (1997). Where did all the growth go? External shocks, social conflict and growth collapses. Harvard: Harvard University.

Samuelson, P. (1989). Economics (13th $E d)$. McGraw Hill.

Siddiqi, M. N. (2004). Kegiatan ekonomi dalam Islam. Jakarta: PT. Bumi Aksara.

Singh, S. (1999). Ten priorities for poverty eradication. United Nations Economic and Social Council (ECOSOC).

Spicker, P. (1995). Social policy: themes and approaches. London: PrenticeHall.

The World Bank. (n.d.). WDI 2016 maps. Retrieved from http://data.worldbank.org

Usmani, T. (2000). The Economic Challenge for the Ummah, International Conference of the World Muslim Congress. Retrieved from http://www.albalagh.net

Veit-Wilson, J. (1998). Setting adequacy standards. How governments define.

White, H., \& Anderson, E. (2001). Growth versus Distribution: Does the Pattern of Growth Matter?. Development Policy Review 19(3), 267-289.

Wodon, Q. T. (1999). Growth, poverty, and inequality: a regional panel. World Bank Policy Research Working Paper, 2072.

World Bank. (1990). World Development Report 1990 : Poverty. New York: Oxford University Press. Retrieved from

https://openknowledge.worldbank.or g/handle/10986/5973 License: CC BY 3.0 IGO.

World Bank. (2001). Attacking Poverty: World Development Report, 2000/2001. New York: Oxford University Press.

Zarqa, M. A., \& Al-Jarhi, M. A. (2007). Redistributive Justice in a 
Developed Economy: An Islamic

Perspective. In M. Iqbal (Ed),

Advance in Islamic economics and finance. Jeddah: IRTI IDB.

Bayu Taufiq Possumah

Sekolah Tinggi Ekonomi Islam Tazkia

Bogor

Indonesia

btaufiq@gmail.com 